This Journal is available in Telkom University online Journals

Jurnal Manajemen Indonesia

\title{
The Role of TQM Practice in Improving Business Performance's Pharmaceutical Industry in Indonesia
}

Fitriyani, Y., ${ }^{1}$ Aziz, Y., ${ }^{2}$ Rivani, R., ${ }^{3}$ Kaltum, U., ${ }^{4}$ Sihotang, J 5

1,2,3,4,5 Padjadjaran University, Faculty of Economics and Business, Master in Management Program, Bandung, Indonesia

\begin{abstract}
The primary purpose of this study is to investigate the role of Total Quality Management (TQM) on business performance in various dimensions. This study proposes a conceptual model that intends to study several research hypotheses. The data were obtained through an online questionnaire, sent to pharmaceutical companies manufactured generic products in Indonesia. The study was conducted based on responses received from 168 valid questionnaires, and it was used partial least squares structural equation modeling (PLS-SEM) to test the hypotheses. Furthermore, we use both of reflective and formative construct with second order/higher order construct in our model of study which is rarely found in the previous study. This research analyzed the dimensions studied in different aspects. TQM variable consists of seven practice, namely management commitment, supplier quality, employee involvement, leadership management, customer orientation, continuous improvement and quality management system, and with respect to business performance, this variable was analyzed through four different perspectives, namely, financial, customer, internal business process and learning \& growth. The findings indicate that companies adopt total quality management get improvement in their business performance. Leadership management has greater effect on the successful of TQM practice compared to other TQM dimensions. This study also provides a particular contribution for the companies and expect to be used as feedback related to the execution of their TQM implementation to improve their business performance.
\end{abstract}

Keywords-Balanced Scorecard; Business Performance; Pharmaceutical Industry; Total Quality Management

\begin{abstract}
Abstrak
Penelitian ini bertujuan untuk mengetahui pengaruh of Total Quality Management (TQM) terhadap kinerja bisnis dalam berbagai dimensi. Penelitian ini mengusulkan model konseptual yang bermaksud untuk mempelajari hipotesis penelitian. Data diperoleh melalui kuesioner online yang disebarkan ke perusahaan farmasi yang memproduksi produk generik di Indonesia. Penelitian ini dilakukan berdasarkan tanggapan yang diterima dari 168 kuesioner yang valid, dan menggunakan Partial Least Square-Structural Equation Modelling (PLS-SEM) untuk menguji hipotesis penelitian. Disamping itu, peneliti menggunakan konstruk reflektif-formatif second order construct/higher order construct dalam model penelitian kami yang jarang sekali ditemukan pada penelitianpenelitian terdahulu. Penelitian ini menganalisis dimensi yang dipelajari dalam berbagai aspek. Variabel TQM terdiri atas tujuh dimensi yaitu komitmen manajemen, kualitas pemasok, keterlibatan karyawan, manajemen kepemimpinan, orientasi pelanggan, perbaikan berkesinambungan dan sistem manajemen mutu, sedangkan variabel kinerja bisnis dianalisis melalui empat perspektif yang berbeda, yaitu, keuangan, pelanggan, proses bisnis internal dan pembelajaran \& pertumbuhan. Hasil penelitian menunjukkan bahwa perusahaan yang mengimplementasikan TQM dapat meningkatkan kinerja bisnis perusahaannya. Manajemen kepemimpinan memiliki efek yang lebih besar terhadap kesuksesan praktik TQM dibandingkan dengan dimensi TQM lainnya. Penelitian ini juga memberikan kontribusi khusus bagi perusahaan dan diharapkan dapat digunakan sebagai umpan balik terkait dengan pelaksanaan TQM pada perusahaan untuk meningkatkan kinerja bisnis mereka.
\end{abstract}

Kata kunci-Balanced scorecard; Kinerja Bisnis; Industri Farmasi; Total Quality Management 


\section{INTRODUCTION}

In last four decades, the manufacturing industry has undergone significant changes involved top management approach, customer expectations, supplier capabilities and technologies used in process and product development Due to high intense of competition in today's global environment, many companies are putting efforts to improve quality and to reduce costs (Modgil \& Sharma, 2016).

Today, pharmaceutical industry in Indonesia is one of the priority sectors. It is considered to provide a significant contribution to the growth of the Indonesian economy. The pharmaceutical industry market grew $7.5 \%$ until the fourth quarter of 2016, higher than the same period in the previous year which was $4.9 \%$ (IMS Health, 2017). The parmaceutical industries are heavily regulated. To obtain a marketing authorization, medicinal products should meet the quality requirement, efficacy and safety standards that have been set in accordance with the regulations for Good Manufacturing Practices (GMP). Mistakes in production can have severe, even fatal, consequences for patients and usually folowed with product recall from the market (Singh \& Dhalla, 2010).

In 2017, laboratory tests were conducted on 15,056 drug samples from a number of distribution facilities and health services (including narcotics and psychotropic drugs). From the results of tests conducted, 124 samples $(0.82 \%)$ did not meet the quality requirements. Those have been followed up with sanctions to the pharmaceutical industry in the form of an order to withdraw drugs from circulation (Indonesian NRA annual report, 2017). Consequently, quality and its management are very important in the pharmaceutical industry. Total Quality Management is a management philosophy which everyone in the organization can strive for customer satisfaction, reduce cost and increase the efficiency of production (Singh \& Dhalla, 2010).

Thus, quality is important for pharmaceutical companies due to strict regulatory requirements, competitive market, global competition, technological advances and emergence of generic product. The challenge for the pharmaceutical industry in Indonesia in the era of Jaminan Kesehatan Nasional (JKN) system implementation is to be able to produce low-cost medicine but in high quality. In terms of quantity, medicine consumption has indeed increased, but sales have decreased, since most medicine used in JKN program was generic drugs which selling price has been set by the government through the Government Agency for Procurement of Goods and Services Policy (LKPP) and the price is not negotiable. Some of pharmaceutical industries in Indonesia face a slowdown in business growth. For example, PT Kalbe Farma Tbk, they experienced a slowdown in business growth from the 2014-2016 period reaching $14.7 \%$. However, in 2016-2017 the company's sales growth was only around $4.5 \%$ (Kalbe Farma's Annual Report, 2017).

This study focuses specifically on pharmaceutical sector of Indonesia to be able to better understand and provide the empirical findings in a particular context and suggest strategic implication that could benefit the firms in that sector, especially for generic product manufacturers. It is also unique as no previous study has been done in the Indonesian generic product manufacturers to the best of the authors' knowledge. Previous studies on pharma business (e.g., Marinkovic, et al., 2016; Mehralian et al., 2012 and Singh \& Dhalla, 2010) provided empirical studies focusing on the relationships between TQM practice and business performance with different condition compared to Indonesian pharmaceutical companies that should be able to produce medicine with low cost but high in quality. Furthermore, we use both of reflective and formative construct with second order/higher order construct in our model of study which is rarely found in the previous study. This paper examines the role of Total Quality Management (TQM) practice on business performance. Specifically, it determines the effect of the seven TQM practice, namely management commitment, supplier quality, employee involvement, leadership management, customer orientation, continuous improvement and quality management system have on business performance. Hence, this paper contributes uniquely in an enriching way for the study of these variables by empirically investigating these relationships in the Indonesian generic product manufacturers.

\section{LITERATURE REVIEW}

\section{A. Total Quality Management (TQM)}

Juran (1998) in Ahmad (2012) stated that Total Quality Management is the basic pillar for lean production practice implementation. Other researcher described that lean production implementation will guide to operational excellence, namely inventory reduction cost, quality improvement and production time decrement. In return, those will lead to financial performance improvement (Hofer et al., 2012 in Ahmad et al., 2012). TQM concerns about quality issues and drives employee to participate in achieving strategic objectives of the company. Business 
effectiveness and efficiency can be improved by implementing TQM in daily activities (Kaur et al., 2012 in Shan et al., 2016). While Daft (2001) in Hanh and Siengthai (2014) stated that TQM is handing over the assignment to staff for handling responsibility autonomously in order to meet quality's standard. Meanwhile, other experts describe TQM as a systematic structure support improvement of constructional factors as well as vendors management and innovation as part of organizational processes (Schroeder et al., 2008 in Silva et al., 2013). Kaynak (2003) in Dabestani et al. (2014) described TQM as a philosophy of holistic management driving improvement applied in the whole function of an organization continually. At last, we can conclude that TQM as activities of management that mainly focus on continual improvement to enhance customer satisfaction by increasing its product and service quality (Jonah et al., 2018).

TQM is a multidimensional construct, consist of several activities. Some researchers mentioned that the TQM dimensions are: top management commitment, leadership, quality management system, customer focus, employee management and training and supplier quality (Singh \& Dhalla, 2010). Other researchers mentioned that TQM dimensions that influence the critical success factors of TQM are: top management commitment, employee involvement, customer focus, fact based management, incentive and recognition system processes, monitoring and control and continuous improvement (Hassan, et al., 2012). Yet this study focus on the seven among the dimensions of TQM; leadership management, continuous improvement, management commitment, supplier quality, customer orientation, employee involvement and quality management system.

\section{B. Business Performance}

At present, evaluation of business performance has become an important element in the development of corporate strategy due to the existence of a global market and intense competitiveness. Individual or group activities contribute to the achievement of organizational goals and objectives which are considered as business performance. Employee knowledge, skills and experience are indicators that are measured in business performance (Chahal et al., 2016).

Bedi (2016) stated that business performance refers to the measurement of financial and operational performance as the overall index of company's ability to satisfy its stakeholders, usually using primary data for 'subjective business performance' measurement and secondary data for 'objective business performance' measurement or using both of them. Meanwhile, some experts stated that market and financial outputs of the company can be used to measure business performance (Rodriguez et al., 2010; Vijande et al., 2013 in Gomis et al., 2018).

Various literatures revealed that financial, personnel and operational achievement perspectives had been used to asses business performance. Based on the perspectives of financial, profitability of company, percentage of retun on investment, growth of sales and growth of earnings are indicators applied by researchers to measure it (Liao \& Wu, 2009; Venkatraman \& Ramanujam, 1986 in Chahal et al., 2016). Many literatures stated that to measure employee performance, we must observe indicators as well as level of employee satisfaction, employee turnover rate, effectiveness of employee, truancy rate, participation level of employee and performance of employee on the whole aspects (Venkatraman \& Ramanujam, 1986 in Chahal et al., 2016: 3S). Lastly, quantity of faulty products or services, number of customer complaints,quality of service or product and market share are indicators to measure operating performance level in a company (Venkatraman \& Ramanujam, 1986; Wright, Gardner \& Moynihan, 2003 in Chahal et al., 2016).

One of the most popular approaches to measure business performance is balanced scorecard (BSC). BSC enables managers to measure their performance in business from the four performance perspectives, namely financial, customer, internal business process and learning \& growth (Khatoon \& Farooq, 2016 and Mehralian $e t$ al., 2015). Robert Kaplan and David Norton developed this approach for the first time. In order to set firms's future visions and provide competitive advantage, financial data should be defined in intangible indicators (Lybildiren \& Karasioglu, 2018). Kaplan \& Norton (1996a) in Lybildiren and Karasioglu (2018) defined balanced scorecard as a measurement based on strategic performance management system by transforming the missions and strategies of the firm into performance criteria set comprehensively as a framework. BSC was developed after previous research that only focused on financial measures failed to measure actual company's business performance. Experts stated that amid knowledge-based business competition, the company's ability to grow, survive and move intangible assets is a critical factor for business success. This type of business performance measurement based only on financial measurement is not enough to capture the company's operational performance including employee skills, customer loyalty and supplier relationships (Muiruri \& Kilika., 2015). 
In this study business performance is defined as performance which is part of the company's business functions support overall company's performance based on four perspectives of balanced scorecard namely financial, customer, internal business process and learning \& growth.

\section{Relationship of TQM and Business Performance}

Total quality management (TQM) is an integrated business management strategy aimed at instilling quality awareness in all company processes (Swink et al., 2014). The International Standards Organization (ISO) defines TQM as a management approach for an organization, which is quality-centered, based on the participation of all its members and aims at long-term success through customer satisfaction and benefits for all members of the organization and also for society (ISO 8402: 1994). Today, Total Quality Management (TQM) can be a major factor in achieving competitive advantage for companies. This is because the TQM concept allows organizations to run the company efficiently, improve employee productivity, materials and also improve product quality (Silva et al., 2013).

In the past few decades, as has been demonstrated through many publications, TQM has a significant role in improving business performance because it affects the growth and performance of the company so that the company continues to achieve continual improvement as an important integral part of its organizational strategy (Jonah et al, 2016). The relationship between TQM and performance has been investigated by many researchers on various types of performance, including financial performance, operational performance and quality performance. Although the effects of TQM on various types of performance are inconsistent, quality performance generally shows a strong and positive relationship (Zehir et al, 2012). According to Deming, quality is the main determinant of the company's success in a competitive business environment. Quality management is an activity that is increasingly important for all types of companies and is associated with corporate strategies to gain competitive advantage (Miego et al, 2009 in Zehir et al, 2012). Other researchers mentioned that some dimensions of TQM, especially those related to leadership and education, have a stronger correlation with business performance (Cetindere et al, 2014). Demirbarg, et al. (2006) stated that there is a strong positive relationship between TQM practices and non-financial performance, while there is only weak influence of TQM practices on financial performance.

To clarify the issue on previous studies, the author are interested in conducting further investigation on the relationship between TQM and business performance. One of the goals of this research is to contribute in an enriching way for the study of these variables to capture current situation of the TQM practices in the pharmaceutical industry in Indonesia to improve their business performance.

\section{Hypotheses Development}

Several studies were designed to investigate the relationship between TQM and business performance. Although the effects of TQM on various types of performance are inconsistent, quality performance generally shows a strong and positive relationship (Zehir et al., 2012). Other researchers revealed that TQM is positively associated with business performance such as financial and profitability (Chaudary et al., 2015, Talib et al., 2013 in Simani and Kenyatta, 2017). However, there are also studies showed that there are no correlation between TQM and business performance (Corredor \& Goni, 2011). Cetindere et al. (2014) has also reveal different perspective that dimensions of TQM related to leadership and education, have a stronger correlation with business performance compared to other dimensions. It is, therefore, necessary to analyze the relationship between the seven dimensions of TQM and business performance based on four perspective of BSC to clarify the issue. The research model is given in figure 1.

Several studies were designed to investigate the relationship between TQM and business performance. Although the effects of TQM on various types of performance are inconsistent, quality performance generally shows a strong and positive relationship (Zehir et al., 2012). Other researchers revealed that TQM is positively associated with business performance such as financial and profitability (Chaudary et al., 2015, Talib et al., 2013 in Simani and Kenyatta, 2017, Hassan et al., 2012). However, Cetindere et al. (2014) revealed different perspective that dimensions of TQM related to leadership and education, have a stronger correlation with business performance compared to other dimensions. It is, therefore, necessary to analyze the relationship between TQM and business performance to clarify the issue, research hypotheses are defined as follows:

Q1: What impact TQM implementation might reflect on business performance?

H0: The implementation of TQM does not reveal an improvement in their business performance

H1: The implementation of TQM reveals an improvement in their business performance. 
Total Quality Management $(x)$ :

1. Leader Management

2. Continuous Improvement

3. Management Commitment

4. Supplier Quality

5. Customer Orientation

6. Employee Involvement

7. Quality Management System

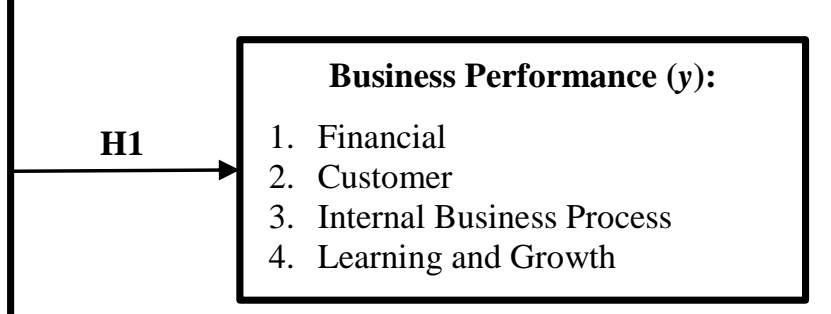

Figure 1. Research Model (Source: Singh and Dhalla, 2010; Hassan, et al. 2012 and Marinkovic et al. 2016)

\section{RESEARCH METHODOLOGY}

This research is conducted at pharmaceutical companies in Indonesia, specifically generic product manufacturers and used a questionnaire survey as instrument to collect of all the data needed for this research. It will be tested whether Total Quality Management in different aspects have an influence on improving the business performance of pharmaceutical companies in Indonesia. There are two parts of the questionnaire, in which the first part contains the questions regarding the demographics of the respondents. While the second part contains a total of 21 items which represent all 8 variables analysed in this research. Out of the total of 21 items, 2 items represent variable leadership management, 1 item represent management commitment, 2 items represent supplier quality, 2 items represent customer orientation, 1 item represents continuous improvement, 1 item represent employee involvement, 1 item represent management quality system and 11 items represent business performance based on the balanced scorecard. Data collected analysis was carried out using Partial Least Square Structural Equation Modeling (PLS-SEM) with reflective-formative construct and the level of analysis is higher/second order construct. Higher order construct (HOC) facilitates modelling a construct on a more abstract higher level of dimensions and its more concrete lower order subdimension as discussed in this study. PLS is a method can be used to analyse both of reflective and formative constructs (Abdillah \& Jogiyanto, 2015). In this study, total quality management is reflective construct. While business performance based on the balanced scorecard is a formative construct based on the fact that the indicators on the balanced scorecard predict its variable. In addition, the non-interchangeable nature of the indicators makes each dimension in the balanced scorecard used to assess business performance in this study as a first order formative construct (Petter et al., 2007 in Jain, 2009). Park, Lee \& Chae (2016) stated that formative constructs provide greater validity in performance measurement using balanced scorecard compared to reflective constructs. Testing between reflective and formative constructs differs from reflective and reflective constructs. Previous researchers used several approaches to specify and estimate the reflective-formative higher order construct (HOC) model in PLS-SEM, namely the repeated indicators approach and the two stage approach. The results showed that the indicator repetition approach produced a smaller bias in estimating the higher order construct measurement model, namely the relationship between the lower and higher order components. In contrast, the two stage approach shows better recovery parameters in path analysis 1) exogenous constructs to HOC, and 2) from HOC to endogenous constructs in the path model (Ringle et al., 2012 and Becker et al., 2012). In this study, we will use the two stage approach to test the research model.

Before research was conducted, a pilot scale study is conducted beforehand for pre-test purpose. Sekaran \& Bougie (2016) and Trochim et al. (2016) had stated that a questionnaire should and required to be pretested adequately before it could be used on the actual survey. A total of 31 respondents who were drawn from the same population and have the same characteristics as the respondents participated in the pilot scale test. After all of the data were collected, validity and reliability test were conducted in order to ensure that all of the data are valid and reliable, and the questionnaire could be used in the research. It was revealed that all items have been deemed as valid and reliable, thus enabling the questionnaire to be used in the research.

Hair, et al., (2017) stated that the minimum use of samples in the Partial Least Square (PLS) analysis is based on (a) ten times the size of the most formative indicators used to measure one latent variable, or (b) ten times the 
highest number of structural paths directed at certain latent variables in the structural model. The structural path indicator in this study is 2 . Thus the minimum PLS sample in this study is at least 20 companies.

The method of distributing questionnaires, using purposive sampling technique and quota sampling method, where non-random sampling previously determined by researchers with the following considerations: information needs for research and characteristics in the population. Sample criteria in this research is pharmaceutical companies in Indonesia manufactured generic drugs and participated in providing drugs for JKN program. Quota sampling is set by determining sample represents at least fifty percent of the market share of the pharmaceutical industry that produced generic drugs and participated in providing drugs for the JKN program, the data obtained is expected to be relevant and represented current situation of the pharmaceutical industry in Indonesia. According to data from the Food and Drug Supervisory Agency and the Indonesian Ministry of Health, as of the second quarter of 2019 there were around 94 pharmaceutical companies producing generic drugs and participating as providers of drugs for the National Health Insurance program (BPJS Kesehatan). Of these, 35 companies have market shares above $0.1 \%$, while the rest have market shares between $0.00 \%-0.09 \%$.

In this research, the questionnaire was distributed using online method. This method provided the benefit of being able to collect a lot of data in a short time. Since this research measures the business performance based on business function, it is determined that respondents for each company are employees at the level of middle management to top management who are responsible for making decisions related to research variables, starting from assistant manager, section chief, manager, head of department, senior manager, general manager and Director. Each company is represented by four respondents so that it is expected to be able to represent four perspectives of company performance based on a balanced scorecard, namely financial, customers, internal business processes and learning \& growth.

Based on questionnaire results received back from managers working in the pharmaceutical industry producing generic drugs and participating in providing drugs for the JKN program during September-October 2019 period, there were 42 pharmaceutical companies with total 168 respondents filled the questionnaire and represented a total market share of generic drugs manufacturers of $77.15 \%$ which means have met the specified quota sampling requirements, which represent a minimum of $50 \%$ of the market share of the generic drug industry and a minimum of 20 companies. After further assessment was made regarding the response given in the questionnaires, all data generated from the questionnaires were deemed valid. Therefore, data collected from a total of 168 questionnaires were used and processed in this research. All data collected then analysed using partial least square-structural equation modelling (PLS-SEM) using SmartPLS 3.2.7 software to determine the validity and reliability of the model and to determine the causal relationship between variables.

\section{RESUlT AND DISCUSSION}

The data obtained is then processed by the PLS-SEM (Partial Least Square-Structural Equation Modeling) using SmartPLS 3.2.7 software. The outer model (structural test) is conducted to confirm the validity and the reliability of the study model. Following that, inner model analysis is determined with the bootstrapping method on to produce the statistical test used ( $t$ test). Significance value used is $\alpha=0.05$, hypothesis is accepted if $t$ statistic is higher than 1.96. Lastly, it is proceeded to a correlation analysis between the constructs on the level of dimensions and indicators of each variable studied in this research and to test the hypotheses proposed in this research using PLS-SEM.

Outer model consists of convergent validity and discriminant validity. Convergent validity for reflective construct (in this research, TQM variable is reflective construct) is achieved if construct indicators have high correlations and have sufficient loading scores. Not only in loading scores, validity is also shown by the convergence of all construct indicators. According to Chin (1995) in Abdillah and Jogiyanto (2015) the Rule of thumb used for convergent validity is outer loading > 0.7, 0.5 and Average Variance Extracted (AVE) $>0.5$. Meanwhile, according to Hair et al., (2017), the loading value $\geq 0.5$ is considered significant. Reliability tests are in line with construct validity used to measure the consistency of respondents in answering question items in questionnaires or research instruments (quantitative). We used composite reliability (CR) to measure reliability, since it measures the true reliability value of a construct (Chin, 1995 in Abdillah \& Jogiyanto, 2015). According to Hair et al., (2017) Rule of Thumb alpha value of Composite reliability must be greater than 0.7 although the value 0.6 is still acceptable. For all the measures, both indices are higher than the evaluation criteria of 0.5 for the loading value and AVE and 0.7 for composite reliability (see table 1). As stated before, business performance 
variable is a formative construct. Parameters to assess its convergent validity using outer weight of each indicator compared to one another to determine which indicator gives the biggest contribution in one construct and VIF (variance inflation factor) to quantify severity of multicollinearity between formative indicators. High correlation is not expected between formative indicators since the indicators in formative models are not interchangeable. VIF $<5$ indicates no critical levels of collinearity (Hair et al., 2017; 145). Both outer weight and VIF value meets the specification (see table 2). In addition, we also asses the discriminant validity. Hair et al., (2017) stated that the discriminant validity assessment has the goal to ensure that a reflective construct has the strongest relationships with its own indicators compared to any other construct in the PLS path model (see table 3).

Table 1. Outer Model Analysis (TQM)

\begin{tabular}{lcccc}
\hline \multicolumn{1}{c}{ TQM Variable } & Items code & Loading Factor & AVE & Composite Reliability \\
\hline Leadership Management (MK) & X2.15 & 0.898 & 0,822 & 0,902 \\
& X2.16 & 0.914 & & 1,000 \\
Continuous improvement (PB) & X2.17 & 1.000 & 1,000 & 1,000 \\
Commitment Management (KM) & X2.18 & 1.000 & 1,000 & 0,844 \\
Supplier Quality (KP) & X2.19 & 0.813 & 0,731 & 0,805 \\
& X2.20 & 0.895 & & \\
Customer orientation (OP) & X2.21 & 0.854 & 0,674 & 1,000 \\
& X2.22 & 0.786 & & 1,000 \\
Employee Involvement (KK) & X2.23 & 1.000 & 1,000 & 1,000 \\
Quality Management system (SMK) & X2.24 & 1.000 & & \\
\hline
\end{tabular}

Table 2. Outer Model Analysis (Business Performance)

\begin{tabular}{lccc}
\hline \multicolumn{1}{c}{ Business Performance } & Item Code & Outer Weight (T Statistics) & VIF \\
\hline Financial Performance (KF) & Y 25 & 1.893 & 2.129 \\
& Y 26 & 4.651 & 3.898 \\
\hline Customer Performance (KC) & Y 27 & 7.175 & 3.004 \\
& Y 28 & 6.154 & 1.342 \\
& Y 29 & 1.707 & 1.145 \\
\hline Internal Business Process Performance (KI) & Y 30 & 6.002 & 1.482 \\
& Y 31 & 2.221 & 1.253 \\
& Y 32 & 3.233 & 1.649 \\
\hline Learning \& Growth Performance (KL) & Y 33 & 3.589 & 1.233 \\
\hline
\end{tabular}

Table 3. Discriminant Validity Analysis

\begin{tabular}{lrrrrrrr}
\hline & KK & KM & KP & MK & OP & PB & SMK \\
\hline KK & $\mathbf{1 . 0 0 0}$ & & & & & & \\
KM & 0.515 & $\mathbf{1 . 0 0 0}$ & & & & & \\
KP & 0.480 & 0.500 & $\mathbf{0 . 8 5 5}$ & & & & \\
MK & 0.621 & 0.746 & 0.566 & $\mathbf{0 . 9 0 6}$ & & & \\
OP & 0.513 & 0.538 & 0.645 & 0.689 & $\mathbf{0 . 8 2 1}$ & & \\
PB & 0.515 & 0.729 & 0.506 & 0.809 & 0.646 & $\mathbf{1 . 0 0 0}$ & $\mathbf{1 . 0 0 0}$ \\
SMK & 0.313 & 0.519 & 0.285 & 0.476 & 0.432 & 0.520 & \\
\hline
\end{tabular}

In the second stage of the analysis, inner model analysis was developed to test the causal relationships between the constructs in order to establish the hypotheses. The value of R-Square was found to be 1.000 (see table 4). R square is the best indicator of the explanatories degree of the regression model. Here, a $100 \%$ linear correlation was found between R square the dependent variable (business performance) and the independent variable (TQM). Based on this result, it could be concluded that variable business performance was explained by the seven practice of TQM by $100 \%$. Thus, from model fit indices values it was found that the model had an acceptable fit. 
Table 4. R-Square value

\begin{tabular}{lr}
\hline \multicolumn{1}{c}{ Variables } & R Square \\
\hline KK & 0.495 \\
KM & 0.669 \\
KP & 0.552 \\
Business Performance (Y) & 1.000 \\
MK & 0.836 \\
OP & 0.688 \\
PB & 0.740 \\
SMK & 0.363 \\
\hline
\end{tabular}

Following that, hypothesis test with the bootstrapping method on SmartPLS 3.0 to produce the statistical test used ( $t$ test). Significance value used is $\alpha=0.05$, hypothesis is accepted if $t$ statistic is higher than 1.96 (Table 5).

Table 5. Path coefficient analysis

\begin{tabular}{lcccc}
\hline \multicolumn{1}{c}{ Relationship } & Cut Off Value & Original Sample (O) & T Statistics & Conclusions \\
\hline KC -> Business Performance (Y) & $>1.96$ & 0.275 & 14.801 & Significant \\
KF -> Business Performance (Y) & $>1.96$ & 0.280 & 14.245 & Significant \\
KI -> Business Performance (Y) & $>1.96$ & 0.363 & 18.162 & Significant \\
KL -> Business Performance (Y) & $>1.96$ & 0.293 & 15.679 & Significant \\
TQM (X2) -> KK & $>1.96$ & 0.703 & 15.178 & Significant \\
TQM (X2) -> KM & $>1.96$ & 0.818 & 32.543 & Significant \\
TQM (X2) -> KP & $>1.96$ & 0.743 & 16.903 & Significant \\
TQM (X2) -> MK & $>1.96$ & 0.914 & $\mathbf{7 1 . 0 8 9}$ & Significant \\
TQM (X2) -> OP & $>1.96$ & 0.830 & 34.005 & Significant \\
TQM (X2) -> PB & $>1.96$ & 0.860 & 42.766 & Significant \\
TQM (X2) -> SMK & $>1.96$ & 0.602 & 12.375 & Significant \\
\hline
\end{tabular}

Table 5 above presents correlation matrix of all variables. It shows high degree of significance correlation between all dimensions of TQM and all dimensions of business performance (correlation is significant at 0.05 level, $\mathrm{p}$ values $<0.05$, T statistics > 1.96). It can be concluded that the seven practices of TQM give positive impact in TQM implementation successfulness in a company.

As previous described, for reflective-formative higher order construct, we will use the two stage approach to test the hypotheses in this research model. First, we run PLS algorithm. The next step is to store the latent variable scores calculated in the PLS algorithm to be used as a new data set and then used as an indicator of measurement for the HOC model in stage two using bootstrapping (see table 6).

Table 6. Hypotheses Test Analysis

\begin{tabular}{lcccc}
\hline Variable correlation & Cut Off Value & Sample Mean (M) & T Statistics & Description \\
\hline $\mathrm{TQM} \rightarrow$ Business Performance $(\mathrm{Y})$ & 1.96 & 0.844 & 32.071 & $\mathrm{H} 1$ accepted \\
\hline
\end{tabular}

Table 6 above confirmed hypotheses H1, the implementation of TQM reveals an improvement in their business performance, with T statistics 32.071 (bigger than cut off value 1.96, level of significance 0.05 ) and $\mathrm{p}$ value 0.000 (bigger than alpha 0.05). The results also support the findings of previous researchers (Simani and Kenyatta, 2017 , Hassan et al., 2012) who revealed clear evidence for the concept that companies implemented TQM reveal an improvement in their business performance in terms of financial and non-financial aspect in manufacturing sectors, similar with business performance based on balanced scorecard. The direction of the positive relationship is indicated by the positive original sample value. Leadership management (MK) give the greatest value of $\mathrm{T}$ statistic $(\mathrm{T}$ statistic $=71.089)$ compared to other dimensions of TQM. This also supports the findings of prior researches (Cetindere et al., 2014) that dimensions of TQM related to leadership and education in companies with quality certificates operating in production industry, have a stronger correlation with business performance compared to other dimensions. Companies should give the necessary education and training about the quality to 
their employees and support the improvement under the leadership of the top management accordingly. It also applied in Pharmaceutical Industry in Indonesia. This finding proves that the role of the leader in the implementation of TQM is very important in pharmaceutical industry, one of the examples is in terms of communicating a quality culture to all employees in the company.

\section{CONCLUSION, IMPLICATION AND LIMITATION}

\section{A. Conclusion}

This study examines the relationship between Total Quality Management (TQM) and business performance. A proposed model comprises seven TQM practices and four perspectives to measure business performance. To test the proposed model, data were collected from a sample of Indonesian pharmaceutical companies' represents at least fifty percent of the market share of the pharmaceutical industry manufactured generic drugs and participated in providing drugs for the JKN program. The results of analysis show that the seven of TQM practices have positive impact to company's business performance improvement in all dimensions. Furthermore, leadership management has the biggest impact on TQM practices compared to other dimensions.

\section{B. Theoretical and Practical Implications}

Several previous studies have been conducted and look into these variables, however, we believe the findings of this research formulate a number of important additions to the existing literature by fill a gap concerning some disagreements identified in previous investigations both of the ambiguity of the findings also concerning the different interpretations of the concepts studied. This research had the particularity to analyse the seven of TQM practices, namely leadership management, continuous improvement, management commitment, supplier quality, customer orientation, employee involvement, and quality management systems. For business performance this research analysed this dimension based on balanced scorecard concept, namely financial, customer, internal business process and learning \& growth perspective. This research also provides a unique contribution to the analysis the role of TQM in improving business performance in Indonesian generic manufacturer companies. Thus it will have strategic implications for the company and expect to be used as feedback related to the execution of TQM implementation promptly to improve their business performance. In addition, managers must be able to combine the implementation of the seven TQM practices to obtain best result in driving of improvement of their business performance, particularly in Indonesian pharmaceutical industry.

\section{Limitations and Future Study}

Limitations of this study should be recognized to provide researchers with future research opportunities. First, respondents for this study are Indonesian pharmaceutical companies that manufactured generic drugs and participated in providing drugs for the JKN program. The firms fit the research purpose because they are affected by JKN implementation. However, other pharmaceutical firms that did not manufacture generic drugs might have been left out of this study, whereas they could be more affected. It would be promising to replicate this research using data collected from firms that produced both of generic and branded products. Furthermore, it may not be possible to generalize our findings for firms that are not manufactured generic products, since our data involves only generic manufacturers firms, the findings of this study may not be applicable to non-generic manufacturer firms. Future studies could be conducted to examine the relationship between TQM practices in both generic product manufacturer firms and branded product manufacturer firms. Second, it would be worthwhile to consider conducting case studies to get an in-depth insight on how TQM-driven firms improve their business performance and why is the most important among TQM practices.

\section{REFERENCES}

Abdillah \& Jogiyanto (2015). Partial Least Square (PLS) alternative Structural Equation Modelling (SEM) dalam Penelitian Bisnis. Yogyakarta: Penerbit Andi.

Ahmad, M.F., Zakuan, N., Jusoh, A., and Takala, J (2012). Relationship of TQM and Business Performance with Mediators of SPC, Lean Production and TPM. Procedia - Social and Behavioral Sciences 65, 186 - 191 
Al-Battaineh (2018). Effect of Innovation Strategies on the Functional Performance of SMEs Organizations in (Hassan Industrial City). International Journal of Business and Management Invention (IJBMI). 7 (5), 1218.

Antunes, MG., Quirós,JT., \& Justino, MRF. (2017). The Relationship Between innovation and total quality management and the innovation effects on organizational performance. International Journal of Quality \& Reliability Management,-1474-1492.

Ar, M., \& Baki, B (2011). Antecedents and Performance Impacts of Product versus Process Innovation: Empirical Evidence from SMEs Located In Turkish Science and Technology Parks. European Journal of Innovation Management, 14 (2), 172-206.

Becker, J.M., Klein, K., \& Wetzels, M. (2012). Hierarchical Latent Variable Models in PLS-SEM: Guidelines for Using Reflective-Formative Type Models. Long Range Planning, 45 (5-6), 359-394.

Bedi, H. S. \& Vij, S. (2016). Are subjective business performance measures justified?. International Journal of Productivity and Performance Management, 65(5),1-33.

Beyene, K.T., Shi, CS., \& Wu, W.W. (2016). The Impact Of Innovation Strategy On Organizational Learning And Innovation Performance: Do Firm Size And Ownership Type Make a Difference?. South African Journal of Industrial Engineering. 27(1), 125-136.

Cetindere, A., Duran, C., and Yetisen, MS. (2014). The effects of total quality management on the business performance: An application in the province of Kütahya. Procedia Economics and Finance. 23 (2015), $1376-1382$.

Chahal, H., Jeevan, J., \& Rani, A. (2016). The effect of perceived high performance human resource practices on business performance: Role of organizational learning. Global Business Review, 17(3S), 1S-26S

Corredor, P., \& Goñi, S. (2011). TQM and performance: Is the relationship so obvious? Journal of Business Research, 64(8), 830-838.

Dabestani, R., Taghafi, A \& Saljoughian,M. (2014). The relationship between total quality management critical success factors and knowledge sharing in a service industry. Management and Labour Studies, 39, 81-101.

David \& David (2017). Strategic Management: a Competitive Advantage Approach, Concepts and Cases. $16^{\text {th }}$ Edition. Harlow, UK: Pearson Education Ltd.

Demirbag, M., Tatoglu, E., Tekinkus, M., \& Zaim, S. (2006). An analysis of the relationship between TQM implementation and organizational performance: Evidence from Turkish SMEs. Journal of Manufacturing Technology Management. 17(6), 829-847.

Hair, J.F., Hult, G., Ringle, C.M., and Sarstedt, M (2017). A Primer on Partial Least Square Structural Equation Modelling (PLS-SEM). Second Edition. Los Angeles: SAGE Publications, Inc.

Hanh, T. T. H. \& Siengthai, S. (2010). The impact of BPR, TQM, OL and ownership structure on product innovation in Vietnamese equitized firms. Asian Journal of Management Research, 4(3), 361-377.

Hassan M, Mukhtar A, Qureshi S.U \& Sharif S (2012). Impact of TQM Practices on Firm's Performance of Pakistan's Manufacturing Organization. International Journal of Academic Research in Business and Social Sciences, Vol 2, 10.

Jain, V. (2009). Assessing value of ERP systems: a formative construct analysis. AMCIS 2009 Proceedings, p. 317. Accessed from http://aisel.aisnet.org/amcis2009/317.

Jonah, N., Ornguga, I.G., and Torsen, E. (2016). The Effect of Total Quality Management (TQM) on the Organizational Growth of Adama Beverages: A Marketing Mix Perspective. International Journal of Science and Research (IJSR), 1-21.

Kim, Kumar and Kumar (2012). Relationship between quality management practices and innovation. Journal of Operations Management, 30, 295-315

Kumar VK and Prasad RS (2017). Total quality management practices in pharmaceutical industry: A study of selected companies in Andhra Pradesh and Telangana states. International Journal of Pharmaceutical science and Research. 2 (6),01-07.

Lyibildire, M. \& Karasioglu, F. (2018). Balanced scorecard in business performance measurement and its effect on financial structure. Global Journal of Management and Business Research: C Finance, 18 (2), 14-21. 
Marinkovic, V., Bekcic, S., Pejovic, G., Sibalija, Tatjana., Majstorovic, V., Tasic, L. (2016). An approach to TQM evaluation in pharma business. The TQM Journal, 28 (5), 745-759.

Mehralian, G., Nazari, J.A., Nooriparto, G., Rasekh, H.R., (2013). TQM and organizational performance using the balanced scorecard approach. International Journal of Productivity and Performance Management, 66(1), 111-125.

Modgil, S. \& Sharma, S. (2016). Total Productive Maintenance, Total Quality Management and Operational Performance: An empirical study of Indian pharmaceutical industry. Journal of Quality in Maintenance Engineering. 22 (4), 353-37.

Muiruri, ZK and Kilika J (2015). The Influence of the Balanced Score Card on Performance of Public Sector Organizations in Kenya. Science Journal of Business and Management, 3(5): 150-156.

Ringle, C. M., Sarstedt, M., \& Straub, D. W. (2012). A critical look at the use of PLS-SEM in MIS Quarterly. MIS Quarterly, 36(1), iii-xiv.

Riyadi S and Sumardi, (2017). The Impact of Innovation Strategy toward Business Competitiveness of Manufacturing Industry in Surabaya, Indonesia. Hasanuddin Economics and Business Review. 1 (1), 8389.

Sarstedt M, Hair J.F, Cheah J.H, Becker,J.M \& Ringle, C.M (2019). How to specify, estimate, and validate higherorder constructs in PLS-SEM. Australasian Marketing Journal, 5:25

Sekaran, U., \& Bougie, R. (2016). Research Methods for Business: A skill-building approach. $7^{\text {th }}$ ed. West Sussex, UK: John Wiley \& Sons Ltd.

Shan, A. W., Fauzi M.A., Hisyamudin M.N. (2016). The mediating effect of innovation between total quality management (TQM) and business performance. IOP Conf. Series: Materials Science and Engineering, $160,012011$.

Silva, MG., Gomes, PJ., Lages, LF., and Pereira, ZL., (2013). The role of TQM in strategic product innovation: an empirical assessment. International Journal of Operations \& Production Management.34 (10), 13071337.

Simani, WL and Kenyatta, J (2017) .TQM Perspectives under the Competitive Strategies and The Organization Performance in Kenyan Manufacturing Sector. Academy of Strategic Management Journal. 16 (2).

Singh, SB \& Dhalla, RS (2010). Effect of Total Quality Management on Performance of Indian Pharmaceutical Industries. Proceedings of the 2010 International Conference on Industrial Engineering and Operations Management. 1-6.

Swink, M., Melnyk, SA., Cooper, M.B., \& Hartley, JL.(2014). Managing Operations Accross the Supply Chain. $2^{\text {nd }}$ Edition. New York, NY: Mc Graw Hill/Irwin.

Tohidi, H. \& Jabbari, M.M. (2012). Product innovation performance in organization. Procedia Technology, 1,521 $-523$.

Trochim, MW., Donnelly, J.P \& Arora, K (2016). Research Method: The Essential Knowledge Base, Second Edition. Boston, MA: Cengage Learning.

Wheelen, TL., Hunger, JD., Hofmann, AN., \& Bamford, CE. (2018). Concepts in Strategic Management and Business Policy-Globalization, Innovation and Sustainability (Vol. Global Edition). Harlow-UK: Pearson Education Ltd.

Zehir, C., Ertosun, OG., Zehir, S., and Müceldilli, B. (2012). Total Quality Management Practices' Effects on Quality Performance and Innovative Performance. Procedia - Social and Behavioral Sciences, 41 (2012), $273-280$.

Zehir, C and Sadikoglu, E (2012). Relationships among Total Quality Management Practices: An Empirical Study in Turkish Industry. Int J Performability Eng. 8(6): 667-678. 